\title{
Effects of Agromorphological Traits of Ethiopian Mustard (Brasica Carinata A. Braun) Landraces in Oil and its Quality Traits
}

\author{
Fekadu Amsalu* \\ Holetta Agricultural Research Center P. O. Box 2003, Addis Ababa, Ethiopia
}

*Corresponding Author: Fekadu Amsalu, Holetta Agricultural Research Center P. O. Box 2003, Addis Ababa, Ethiopia

\begin{abstract}
The experiment was carried out to assess the effects of agro morphological traits on quantity and quality of oil productions of Ethiopian mustard landraces at Holetta Agricultural research Center, Ethiopia. Therefore forty nine genotypes of Ethiopian mustard land races collected from different agro ecologies were evaluated to assess the effect of agro morphological traits on quantity and quality of oil traits produced. The experiment was carried out in a simple lattice design. Univariate analysis of variance showed that there were significant differences among genotypes for all agro morphological traits, quantity and oil quality related traits compared. The significant difference indicates the existence of genetic variability reflection in genetic effects of agro morphological traits among the accessions which is important for improvement of these traits. The present study revealed the presence of considerable variability among genotypes for all traits assessed. The significant difference of results indicates that the presence of good opportunity to improve these agro morphological, oil yield quantity and quality related traits of Ethiopian mustard using the tested genotypes.
\end{abstract}

Keywords: Ethiopian mustard agro morphological traits, Oil, Oil quality traits, Univariate, Analysis

\section{INTRODUCTION}

The genus Brassica of Brassicaceae family as a whole is believed to have originated around the Mediterranean, Eastern Afghanistan and the adjoining portion of Pakistan and North-Eastern Africa (Hemingway, 1976). The genus includes six economically important species, namely, Brassica rapa, B. oleracea, B. nigra, B. juncea, B. napus, and B. carinata (Doweny and Robbelen, 1989). Ethiopian mustard is believed to be originated in the highlands of the Ethiopian plateau and the adjoining portion of East Africa and the Mediterranean coast (Gomez-Campo and Prakash, 1999).It evolved as a natural cross between $B$. nigra $(\mathrm{BB})(\mathrm{n}=8)$ and $B$. oleracea $(\mathrm{CC})(\mathrm{n}=9)$ and underwent further chromosomal doubling $(2 \mathrm{n}=34 ; \mathrm{UN}, 1935)$. It is partially amphidiploids.

The crop is traditionally used for many purposes, such as greasing traditional bread-baking clay pan, curing certain diseases and as a source of vegetable relish (Nigussie, 2001). It is the only highland oil seed vegetable crop able to consume by defoliating its leaves or sold to generate income after month of sowing in most near big city parts of the country. Crop improvement through plant breeding, thus, occurs through selection operating on genetic variability. Genetic variability is therefore essential for crop improvement. In characterization of Ethiopian mustard for vegetative agro-morphological traits Jane Muthoni, (2010) reported as great variation was seen in leaf number per plant, leaf bloom and leaf blade blistering. Identifying agro morphological traits of Ethiopian mustard that is heritable to be reflected as effects on quantity and quality of oil production is crucial for further investigation of improvement program of the crop. Therefore the present study was, executed with the objective of assessing the effect of agro morphological traits of Ethiopian mustard land races in relation to quantity and quality of oil production.

\section{MATERIALS AND METHODS}

\section{Experimental Site}

The experiment was conducted at Holetta Agricultural Research Center in 2013/2014 cropping season from June to December 2013. Holetta (West Shewa Zone of Oromia Region) is located at latitude $9^{\circ}$ 
Effects of Agromorphological Traits of Ethiopian Mustard (Brasica Carinata A. Braun) Landraces in Oil and its Quality Traits

$\mathrm{N}$ and longitude $38^{\circ} \mathrm{E}$, altitude of $2400 \mathrm{~m}$ a.s.l situated $30 \mathrm{~km}$ West of Addis Ababa. It is one of the representatives of oil seed Brassica growing areas in the central highlands of Ethiopia (Nigussie and Mesfin, 1994). The area has a mean annual rainfall of $1059 \mathrm{~mm}$ and temperatures of $23^{\circ} \mathrm{C}$ (maximum) and $8^{\circ} \mathrm{C}$ (minimum). The soil type is Nitisols with soil ph in the range of $6.0-7.5$ (Nigussie and Mesfin, 1994).

\subsection{Description of Test Materials}

A total of forty-nine mustard land races that include one local check and one standard check were used in this study. The majority of the accessions represent the national collection from different major mustard growing regions of the country and that are maintained at Holetta agricultural research Center. The accessions were obtained kindly from Holetta agricultural research center of highland oil crops improvement project. The details of the accessions used in the experiment are given in Table 1.

Table1. List of 49 Ethiopian mustard genotypes used in the study and their origin

\begin{tabular}{|c|c|c|c|c|c|}
\hline No. & Accession number & Area of collection & Altitude(m) & Latitude & Longitude \\
\hline 1 & PGRC/E 20001 & West Wollega/Arjo & 2420 & $08-44-00 \mathrm{~N}$ & $36-40.00 \mathrm{E}$ \\
\hline 2 & 20002 & Bale Zone/Kitu & 2500 & $06-.59 .00 \mathrm{~N}$ & $39-12-00 \mathrm{E}$ \\
\hline 3 & 20004 & South Gonder/Liba & 1980 & $12-.05-00 \mathrm{~N}$ & $37-44-00 \mathrm{E}$ \\
\hline 4 & 20005 & SouthGonder/Debretabor & 1830 & $11-57-00 \mathrm{~N}$ & $37-37-00 \mathrm{E}$ \\
\hline 5 & 20006 & South Gonder/Debretabor & 1980 & $11-50-00 \mathrm{~N}$ & 37-37_00E \\
\hline 6 & 20007 & North Gonder/Woger/Dabat & 2500 & $*$ & $*$ \\
\hline 7 & 20017 & West Gojiam /Awi /Dangila & 1980 & $11-.20-00 \mathrm{~N}$ & $36-58-00 \mathrm{E}$ \\
\hline 8 & 20056 & West Shewa/Jibatenamecha & 2200 & $09-01-00 \mathrm{~N}$ & $38 .-20-00 \mathrm{E}$ \\
\hline 9 & 20065 & West Shewa/Jibatena mecha & 2200 & $08-58-00 \mathrm{~N}$ & $37-30.00 \mathrm{E}$ \\
\hline 10 & 20066 & West Shewa/Ambo & 1950 & $08-.59 .00 \mathrm{~N}$ & $37-48-00 \mathrm{E}$ \\
\hline 11 & 20067 & West Shewa/Ambo & 2010 & $08-.58-00 \mathrm{~N}$ & $37-52-00 \mathrm{E}$ \\
\hline 12 & 20076 & SNNP/Wenago & 1853 & $06-23-00 \mathrm{~N}$ & $38-20-00 \mathrm{E}$ \\
\hline 13 & 20077 & South East Tigray/Inderta & 2000 & $13-29-00 \mathrm{~N}$ & $39-30.00 \mathrm{E}$ \\
\hline 14 & 20112 & West Gojam/JabiTehnan & 1980 & $10-.39 .00 \mathrm{~N}$ & $37-24-00 \mathrm{E}$ \\
\hline 15 & 20117 & West Shewa/Jibatnamecha & 2050 & $08-.58-00 \mathrm{~N}$ & $38-01-00 \mathrm{E}$ \\
\hline 16 & 20127 & West Shewa/chelia & 1700 & $09-03-00 \mathrm{~N}$ & $37-10-00 \mathrm{E}$ \\
\hline 17 & 20133 & West Shewa/Menagesha & 2600 & $09-11-00 \mathrm{~N}$ & $39-09.00 \mathrm{E}$ \\
\hline 18 & 20134 & West Shewa/Jibat & 2200 & $08-.58 .00 \mathrm{~N}$ & $37-30-00 \mathrm{E}$ \\
\hline 19 & 20146 & West Gojam/Bahirdarzuria & 1980 & $11-.25-00 \mathrm{~N}$ & $37-12-00 \mathrm{E}$ \\
\hline 20 & 20165 & West Gojiam/Awi/Dangila & 1980 & $11-20-00 \mathrm{~N}$ & $36-58-00 \mathrm{E}$ \\
\hline 21 & 20166 & West Gojiam/Awi/Dangila & 1980 & $11-20-00 \mathrm{~N}$ & $36-58.00 \mathrm{E}$ \\
\hline 22 & 21008 & Arsi/Gedeb & 2380 & $07-.12 .00 \mathrm{~N}$ & 38-09-00E \\
\hline 23 & 21012 & West shewa/Dendi & 2900 & $09-.14-00 \mathrm{~N}$ & $38-53-00 \mathrm{E}$ \\
\hline 24 & 21017 & West Shewa/Gendbert & 2470 & $09-43-00 \mathrm{~N}$ & $37-46-00 \mathrm{E}$ \\
\hline 25 & 21026 & West Gojiam Awi/Dangila & 2000 & $11-18-00 \mathrm{~N}$ & $36-58.00 \mathrm{E}$ \\
\hline 26 & 21035 & West Gojam/Sekela & 2540 & $10-.50-00 \mathrm{~N}$ & $37-04-00 \mathrm{E}$ \\
\hline 27 & 21037 & West Gojiam/Awi/Dangila & 2165 & $11-.14-00 \mathrm{~N}$ & $36-51-00 \mathrm{E}$ \\
\hline 28 & 21068 & Bale/Adaba & 2500 & $07-01-00 \mathrm{~N}$ & $39-25-00 \mathrm{E}$ \\
\hline 29 & 21157 & SNNP /South omo & 2830 & $06-19-00 \mathrm{~N}$ & $38-52-00 \mathrm{E}$ \\
\hline 30 & 21225 & East Gojam/Enemay & 2000 & $10-.32-00 \mathrm{~N}$ & 38-09-00E \\
\hline 31 & 208411 & West Gonder/Debretabor & 2150 & $11-.50-00 \mathrm{~N}$ & $37-35-00 \mathrm{E}$ \\
\hline 32 & 229665 & West Gojam/Burie & 2050 & $10-33-00 \mathrm{~N}$ & $37-34-00 \mathrm{E}$ \\
\hline 33 & 237048 & Arsie-Robe & 2350 & $07-08-00 \mathrm{~N}$ & $40-00.00 \mathrm{E}$ \\
\hline 34 & 241907 & South Gonder/Fogera & 1825 & $12-.01-00 \mathrm{~N}$ & $37-43-00 \mathrm{E}$ \\
\hline 35 & 241910 & South Gonder/Farta & 2289 & $11-.49-00 \mathrm{~N}$ & $38-00-00 \mathrm{E}$ \\
\hline 36 & 242856 & Arsi zone /Sherka & 2360 & $07-32-64 \mathrm{~N}$ & $39-37-87 \mathrm{E}$ \\
\hline 37 & 242858 & Arsi zone /Sherka & 2360 & $07-34-27 \mathrm{~N}$ & $39-31-24 \mathrm{E}$ \\
\hline 38 & 243738 & South Wollo/Desiezuria & 2928 & $11-08-00 \mathrm{~N}$ & $39-13-00 \mathrm{E}$ \\
\hline
\end{tabular}


Effects of Agromorphological Traits of Ethiopian Mustard (Brasica Carinata A. Braun) Landraces in Oil and its Quality Traits

\begin{tabular}{|c|c|c|c|c|c|c|}
\hline 39 & $"$ & 243739 & South Wollo/Tenta & 2950 & $11-.14-00 \mathrm{~N}$ & $39-15-00 \mathrm{E}$ \\
\hline 40 & $"$ & 21256 & West Gojam/Bahirdarzuria & 1940 & $11-16-00 \mathrm{~N}$ & $36-59-00 \mathrm{E}$ \\
\hline 41 & " & 243750 & Wollo/kalu & 2020 & $11-45-00 \mathrm{~N}$ & $39-47.00 \mathrm{E}$ \\
\hline 42 & " & 2243756 & South Gonder/ Debark & 3115 & $11-.08 .00 \mathrm{~N}$ & $37-56-00 \mathrm{E}$ \\
\hline 43 & " & 243761 & Gonder Zuria & 2050 & $12-.19-00 \mathrm{~N}$ & $37-33-00 \mathrm{E}$ \\
\hline 44 & " & 243763 & South Gonder/Kemkem & 2070 & $11-57-00 \mathrm{~N}$ & $37-37-00 \mathrm{E}$ \\
\hline 45 & " & 208556 & West Shewa/Adis Alem & 2200 & $*$ & $*$ \\
\hline 46 & $"$ & 208585 & East Shewa/yerer & 1600 & $*$ & $*$ \\
\hline 47 & Yell & $\mathrm{v}$ dodolla & Bale/Dodolla & 2500 & $06-.59-00 \mathrm{~N}$ & $39-12-00 \mathrm{E}$ \\
\hline 48 & (Zem & K Yellow Dodolla ) & Cross & 2400 & $09-00-00 \mathrm{~N}$ & $38-00-00 \mathrm{E}$ \\
\hline 49 & & cal check & Holetta area & 2400 & $09-00-00 \mathrm{~N}$ & $38-00-00 E$ \\
\hline
\end{tabular}

Source: Holetta highland oil crops research program, *=information not found

\subsection{Experimental Design, Management and Season}

The experiment was executed from June 2013 to December 2013. The experiment was laid out in simple lattice design with two replications. A plot of four central rows each three-meter long and $30 \mathrm{~cm}$ spacing between rows were used for data collection. Each replication had seven blocks and each block was represented by seven plots. The path between blocks was $2 \mathrm{~m}$ and the spacing between plots with in sub-blocks was also $0.6 \mathrm{~m}$. Each entry was manually drilled a rate of $10 \mathrm{~kg} / \mathrm{ha}$ and urea and phosphorous fertilizers were applied at the rates of $46 / 69 \mathrm{~kg} / \mathrm{ha} \mathrm{N} / \mathrm{P}_{2} \mathrm{O}_{5}$ respectively following the national recommendations. All other recommended agronomic and cultural practices were carried out following practices described by Adefris (2005).

\section{Data collected}

\section{- Data Collected on Plot Basis}

1. Seed yield per plot (SYP): Seed yield per plot measured in grams after moisture of the seed was adjusted to 7 percent.

2.Oil content (Oc): The proportion of oil in the seed to total oven dried seed weight measured by nuclear magnetic resonance spectroscope as described by Oregon state university seed laboratory proudly procedures._WWW. Seed lab oregonstate. ed/node/158.

3. Oil yield (Oy): The amount of oil in grams obtained by multiplying seed yield per plot by corresponding oil percent.

4. Oil quality trait analysis: oil quality traits like palmic, stearic, oleic, linoleic, linolenic, and erucic acid were measured by nuclear infrared spectroscope.

\section{- On plant basis.}

These data was collected from five plants randomly selected from the central rows of each plot and averaged for statistical analysis.

1. Petiole length: average measurements of the petiole length from bottom, middle and top of five plants of leaves excluding leaves.

2. Leaf length $(\mathrm{cm})$ : average measurements of the leaf length from bottom, middle and top of five plants. From each leaf starting from the base to the apex of leaf blade excluding petiole was measured at full vegetative stage.

3. Leaf width $(\mathrm{cm})$ : An actual measurement across the widest portion/section of the same leaf was at full vegetative stage.

4. Leaf area index: was measured using leaf area meter from bottom, middle and top of five plants for three leaf blade.

\section{RESULTS AND DISCUSSION}

The analysis of variance for the 13 agro morphological and oil quality related traits studied is given in Table 2. The analysis of variance showed that there were significant differences among genotypes for 
all agro morphological, oil yield quantity and oil quality related traits compared. Among analyzed agro morphological traits highly and significantly differences were observed in date of maturity, oil content percent, petiole length, leaf length, leaf width, leaf area and for all oil quality related traits. The significant difference indicates the existence of genetic variability among the accessions that is important for selection and breeding. Yared,(2010) studied thirty six genotypes of mustard seed yield per plot, oil content, oil yield, number of seed per plant, palmatic, stearic, oleic, linoleic linolenic and erucic acid of traits found the same result. Similarly Rabbani et al, studied 52 mustard accessions for various both agronomic and physiological interest (Revilla and Tracy, 1995) and found considerable level of diversity among the executed experiment.

Table2. Mean squares for different sources of variations for 13 agro morphological and oil quality traits of Ethiopian mustard

\begin{tabular}{|c|c|c|c|c|}
\hline Characters & Genotype (48) & Block (12) & Replication(1) & Intera-block error (36) \\
\hline Date of Maturity & $141.98^{*}$ & 6.39 & 0.91 & 9.96 \\
\hline Seed yield per plot & $503441^{*}$ & 925530 & 7543862 & 231667 \\
\hline Oil content & $3.4446^{* *}$ & $1.3825 n \mathrm{n}$ & 217.51 & 1.1283 \\
\hline Oil yield & $108661^{*}$ & 167934 & 2098030 & 46331 \\
\hline Petiole length & $11.6242^{* *}$ & 2.7005 & 32.229 & 2.6565 \\
\hline Leaf length & $6.1553^{*}$ & 2.072 & 22.6368 & 2.4629 \\
\hline Leaf width & $5.8638^{* *}$ & 1.8471 & 22.5408 & 2.1336 \\
\hline Leaf area & $7.3403^{* *}$ & 2.0052 & 25.0026 & 2.1764 \\
\hline Palmic acid & $0.2691^{* *}$ & 0.0661 & 0.0072 & 0.05179 \\
\hline Stearic acid & $0.034^{* *}$ & 0.0073 & 0.0002 & 0.00757 \\
\hline Oleic acid & $2.2211^{* *}$ & 1.1983 & 4.1164 & 0.598 \\
\hline Linoleic acid & $2.2839^{* *}$ & 1.5701 & 4.1291 & 0.4673 \\
\hline Linolenic acid & $11.342^{* *}$ & 1.444 & 7.3909 & 1.3781 \\
\hline Erucic acid & $7.165^{* *}$ & 4.959 & 23.078 & 1.846 \\
\hline
\end{tabular}

$*, * *$ significant at $p=0.05$ and 0.01 significance level, respectively; $n s=$ non-significant

Mean and Range Values of Ethiopian mustard Agro morphological and Oil quality related Traits

The mean performance of the studied genotypes for effects of 13 agro morphological and oil quality related traits are presented in Table 3. The range of seed yield per plot was from 904 to $3297 \mathrm{~kg}$ of seeds. Among the tested genotypes 24 genotypes which are 48.99 percent had shown greater seed yield per plot than the grand mean value while 25 genotypes, i.e. 51.02 percent, showed least mean value than the grand mean.

The oil content of genotypes tested ranged $39.1 \%$ to $46.0 \%$ while oil yield ranges from $370.4 \mathrm{~kg}$ to1478kg. The maximum oil content was recorded by genotype PGRC/E 208585 and the minimum was also recorded for the genotype PGRC/E20133. Mean values for the genotypes of PGRC/E20112, PGRC/E 20165, PGRC/E21026 and PGRC/E 21256, PGRC/E 208585 shows 45.4\%, 44.7\%, 45.5\% and 44.5 and $46.0 \%$ the highest oil content than the standard check yellow dodolla $(44.4 \%)$ respectively. The maximum oil yield was recorded for the standard check yellow dodolla genotype and the minimum oil yield was recorded for genotype PGRC/E20065. From the studied genotypes none of genotypes showed greater oil yield than the standard check yellow dodolla. The mean value of the 25 genotypes tested for this study had shown greater oil content percent than the grand mean of the tested genotypes. Similarly 23 genotypes showed greater oil yield than grand mean of oil yield.

Similarly the mean of leaf length, leaf width and leaf area agro morphological traits are presented in Table 3. Mean value of leaf length of the tested genotypes ranged from $4.6 \mathrm{~cm}$ to $11.2 \mathrm{~cm}$. The longest leaf length $(11.8 \mathrm{~cm})$ was recorded for the genotype PGRC/E243756 while the shortest leaf length $(4.6 \mathrm{~cm})$ was recorded for the genotype PGRC/E 21068. The mean value for Leaf width ranges from $2.1 \mathrm{~cm}$ for genotype PGRC/E 21068 and $8.8 \mathrm{~cm}$ for the genotype PGRC/E 2243756.The mean value of leaf area for the tested genotypes also ranges $3.1 \mathrm{~cm}$ for the genotype PGRC/E21068 to 10.6 $\mathrm{cm}$ for the genotype PGRC/E243756. Among the tested genotypes for leaf length, leaf width and leaf area the mean value of all these characters indicated that genotype PGRC/E 243756 was the first.

The mean and range values of the studied 49 genotypes of Ethiopian mustard for oil quantity and quality parameters are presented in table 3 . Regarding seed oil quality traits, the palmic, stearic, oleic, linoleic, linolenic, and erucic acid of the genotypes ranged from 2.76 to $4.55,0.64$ to $1.17 \%, 6.91$ to 
$11.51,15.59$ to $20.9,9.61$ to 17.39 and $40.1-49.1$ respectively. The highest palmic mean value was shown by the genotype PGRC/E21225 where as the lowest was by the genotype PGRC/E 20065. The highest value of stearic (1.174)was shown by the genotype PGRC/E 208411 and the lowest (0.64) by genotype PGRC/E 21008.The highest value of oleic acid(11.51) was shown by genotype PGRC/E 20017, whereas the lowest(6.91) was by genotype (zem x yellow). The highest value (20.09) for linoleic was recorded by genotype PGRC/E 21225 and the lowest (15.59) was recorded by genotype PGRC/E 21017.

The highest mean value (17.39) for linolenic was recorded by genotype PGRC/E 21008 and the lowest (7.61) was recorded by genotype PGRC/E 208411. Among tested genotypes the highest oil content (46.0\%) was recorded for PGRC/E 208585and the lowest for the genotype PGRC/E20133. Generally, these results indicate that those traits which had wide range of variations will serve for breeding and selection for improvement of the trait desired. A wide range of variations was recorded for traits for example Date of maturity, seed yield per plot, oil content, oil yield, Leaf length, leaf width, etc.

Table3. Mean and range values of the studied 49 genotypes for 13 agro morphological and oil quality traits of Ethiopian mustard tested at Holetta, 2013/14

\begin{tabular}{|c|c|c|c|c|c|c|c|c|c|c|c|c|c|c|}
\hline \multicolumn{2}{|c|}{ Genotypes } & \multirow{2}{*}{\begin{tabular}{|c|} 
DF \\
195
\end{tabular}} & \multicolumn{2}{|c|}{ SYPP OC } & \multirow{2}{*}{\begin{tabular}{|c|} 
OY \\
904
\end{tabular}} & \multirow{2}{*}{\begin{tabular}{|l} 
LL \\
10.5
\end{tabular}} & \multirow{2}{*}{$\frac{\mathrm{LW}}{6.0}$} & \multirow{2}{*}{\begin{tabular}{|l} 
LA \\
8.2
\end{tabular}} & \multicolumn{3}{|c|}{ Palmic|StearicOleic } & \multicolumn{3}{|c|}{ LinoleicLinolenicErucic } \\
\hline 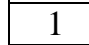 & PGRC/E 20001 & & 2045 & 43.8 & & & & & 3.96 & 0.93 & 9.47 & 16.99 & 10.94 & $4=1$ \\
\hline 2 & 20002 & 81 & 1334 & 41.9 & 472 & 5.5 & 3.3 & 4.2 & 3.83 & 0.72 & 8.16 & 19.21 & 15.18 & 45.95 \\
\hline 3 & 20004 & 90 & 1390 & 42.5 & 609 & 8.2 & 4.6 & 6.1 & 3.64 & 1.05 & 9.90 & 16.80 & 10.05 & 1270 \\
\hline 4 & 20005 & 86 & 1805 & 42.9 & 773 & 6.8 & 4.6 & 5.7 & 3.94 & 0.82 & 9.77 & 17.86 & 3.95 & 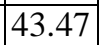 \\
\hline 5 & 20006 & 99 & 1733 & 42.7 & 748 & 8.9 & 6.5 & 7.8 & 3.46 & 0.97 & 9.50 & 16.88 & 10.83 & 43.53 \\
\hline 6 & 20007 & 90 & 1975 & 43.2 & 881 & 8.1 & 5.0 & 6.3 & 3.60 & 0.86 & 8.74 & 16.96 & 12.33 & 44.63 \\
\hline 7 & 20017 & 94 & 1866 & 43.5 & 817 & 9.6 & 6.2 & 7.6 & 3.40 & 1.05 & 11.51 & 16.82 & 10.54 & 40.47 \\
\hline 8 & 20056 & 102 & 1226 & 41.8 & 515 & 7.4 & 6.0 & 7.2 & 3.79 & 0.98 & 9.50 & 17.24 & 10.18 & 44.13 \\
\hline 9 & 20065 & 113 & 904 & 41.0 & 370 & 10.3 & 6.8 & 9.4 & 2.76 & 1.14 & 9.75 & 15.99 & 9.42 & 40.09 \\
\hline 10 & 20066 & 91 & 1375 & 42.2 & 583 & 10.5 & 8.0 & 9.7 & 4.09 & 1.03 & 10.42 & 16.20 & 38 & 44.30 \\
\hline 11 & 20067 & \begin{tabular}{|l|}
89 \\
\end{tabular} & 2534 & 44.0 & 1106 & 7.6 & 4.7 & 6.1 & 4.09 & \begin{tabular}{|l|}
0.95 \\
\end{tabular} & 9.25 & 16.96 & 2.76 & 45.70 \\
\hline 12 & 20076 & \begin{tabular}{|l|}
94 \\
\end{tabular} & 2580 & \begin{tabular}{|l|}
43.0 \\
\end{tabular} & 1101 & 9.4 & 5.6 & 7.5 & 3.47 & \begin{tabular}{|l|}
1.02 \\
\end{tabular} & 9.30 & 17.00 & 10.24 & 43.46 \\
\hline 13 & 20077 & 85 & 1883 & 42.1 & 805 & 7.7 & 4.1 & 5.8 & 4.42 & \begin{tabular}{|l|}
0.67 \\
\end{tabular} & 7.20 & 18.30 & 16.44 & 49.07 \\
\hline 14 & 20112 & \begin{tabular}{|l|}
98 \\
\end{tabular} & 2406 & 45.4 & 1084 & 8.8 & 6.9 & 7.5 & 3.56 & 1.00 & 9.51 & 16.75 & 10.67 & 42.25 \\
\hline 15 & 20117 & 104 & 2080 & 43.0 & 901 & 9.6 & 7.0 & 8.5 & 4.02 & 1.09 & 9.51 & 16.31 & 24 & 43.68 \\
\hline 16 & 20127 & \begin{tabular}{|l|}
107 \\
\end{tabular} & 1846 & 42.4 & 789 & 10.6 & 7.4 & 9.4 & 4.08 & 1.02 & 11.36 & 16.83 & 10.39 & 41.83 \\
\hline 17 & 20133 & 85 & 999 & 39.1 & 398 & 5.8 & 3.2 & 4.2 & 4.51 & \begin{tabular}{|l|}
0.90 \\
\end{tabular} & 9.56 & 19.37 & 57 & 45.66 \\
\hline 18 & 20134 & 102 & 2473 & \begin{tabular}{|l|}
42.4 \\
\end{tabular} & 1044 & 11.1 & 8.1 & 10.1 & 4.26 & \begin{tabular}{|l|}
1.02 \\
\end{tabular} & 10.27 & 16.12 & 0.07 & 44.22 \\
\hline 19 & 20146 & 92 & 2360 & 43.7 & 1031 & 8.8 & 5.8 & 6.9 & 3.85 & \begin{tabular}{|l|}
0.91 \\
\end{tabular} & 9.73 & 18.42 & 12.61 & 42.97 \\
\hline 20 & 20165 & \begin{tabular}{|l|}
97 \\
\end{tabular} & 2465 & 44.7 & 1111 & 10.3 & 7.2 & 8.5 & 3.65 & \begin{tabular}{|l|}
0.95 \\
\end{tabular} & 10.17 & 16.35 & 11.46 & 42.41 \\
\hline 21 & 20166 & \begin{tabular}{|l|}
94 \\
\end{tabular} & 2362 & 43.5 & 1026 & 8.7 & 5.8 & 7.1 & 3.81 & 0.93 & 9.98 & 17.00 & 12.28 & 43.95 \\
\hline 22 & 21008 & 82 & 1637 & 43.5 & 713 & 5.9 & 3.3 & 4.4 & 3.61 & 0.64 & 7.50 & 18.65 & 17.39 & 46.41 \\
\hline 23 & 21012 & 102 & 2162 & \begin{tabular}{|l|}
43.2 \\
\end{tabular} & 945 & 8.4 & 6.3 & 7.5 & 3.35 & \begin{tabular}{|l|}
1.10 \\
\end{tabular} & 10.73 & 16.98 & .71 & 40.61 \\
\hline 24 & 21017 & 105 & 2240 & 42.6 & 980 & 9.4 & 7.0 & 8.6 & 3.67 & 1.10 & 10.39 & 15.59 & 9.27 & 43.03 \\
\hline 25 & 21026 & \begin{tabular}{|l|}
99 \\
\end{tabular} & 3054 & 45.5 & 1364 & 9.0 & 6.7 & 7.5 & 3.78 & \begin{tabular}{|l|}
1.07 \\
\end{tabular} & 10.41 & 16.72 & 9.21 & 42.57 \\
\hline 26 & 21035 & 106 & 1643 & 43.3 & 700 & 10.9 & 8.4 & 10.3 & 3.96 & \begin{tabular}{|l|}
0.91 \\
\end{tabular} & 10.29 & 17.96 & 12.26 & 43.74 \\
\hline 27 & 21037 & \begin{tabular}{|l|}
94 \\
\end{tabular} & 2639 & \begin{tabular}{|l|}
43.1 \\
\end{tabular} & 1217 & 9.9 & 7.1 & 8.7 & 3.69 & 1.05 & 10.52 & 17.72 & 54 & 41.80 \\
\hline 28 & 68 & \begin{tabular}{|l|}
79 \\
\end{tabular} & 1804 & 41.3 & 739 & 4.6 & 2.1 & 3.1 & 3.19 & 0.72 & 7.24 & 17.42 & 78 & 46.82 \\
\hline 29 & 21157 & \begin{tabular}{|l|}
90 \\
\end{tabular} & 1342 & \begin{tabular}{|l|}
41.1 \\
\end{tabular} & 585 & \begin{tabular}{|l|}
10.4 \\
\end{tabular} & 7.6 & 9.4 & 3.57 & \begin{tabular}{|l|}
0.92 \\
\end{tabular} & 10.07 & 17.28 & 14.26 & 41.81 \\
\hline 30 & 21225 & 79 & 1928 & 41.5 & 809 & 6.0 & 2.6 & 3.8 & 4.55 & \begin{tabular}{|l|}
0.79 \\
\end{tabular} & 9.72 & 20.09 & 15.17 & 44.68 \\
\hline 31 & 208411 & 100 & 1586 & 43.9 & 704 & 8.0 & 5.3 & 6.7 & 3.32 & \begin{tabular}{|l|}
1.17 \\
\end{tabular} & 10.75 & 17.32 & 7.61 & 42.63 \\
\hline 32 & 229665 & 100 & 1904 & 43.7 & 817 & 11.0 & 8.2 & 9.2 & 4.13 & 1.05 & 9.69 & 16.98 & 9.78 & 43.28 \\
\hline 33 & PGRC/E 237048 & 109 & 1688 & 41.5 & 713 & 10.9 & 8.1 & 9.8 & 4.27 & \begin{tabular}{|l|l|}
0.71 \\
\end{tabular} & 7.32 & 18.76 & 12.70 & 48.28 \\
\hline 34 & 241907 & 93 & 1988 & 41.6 & 848 & 8.1 & 5.7 & 6.8 & 3.78 & \begin{tabular}{|l|}
0.93 \\
\end{tabular} & 9.04 & 16.83 & 35 & 45.03 \\
\hline 35 & 241910 & 93 & 2566 & 43.1 & 1100 & 8.0 & 5.5 & 6.8 & 3.84 & 0.94 & 10.33 & 17.40 & 12.50 & 44.29 \\
\hline 36 & 242856 & 90 & 2135 & 41.5 & 892 & 7.7 & 4.5 & 6.1 & 4.09 & 0.85 & 8.97 & 18.85 & 13.48 & 43.62 \\
\hline 37 & 242858 & 97 & 2019 & 41.3 & 832 & 9.5 & 6.3 & 8.6 & 4.11 & 0.94 & 10.41 & 17.78 & 11.65 & 43.67 \\
\hline 38 & 243738 & 88 & 2022 & 41.3 & 862 & 6.8 & 3.7 & 4.9 & 4.01 & 0.83 & 9.13 & 18.98 & 15.07 & 45.31 \\
\hline 39 & 243739 & 86 & 2231 & 44.2 & 982 & 5.7 & 3.4 & 4.5 & 4.23 & \begin{tabular}{|l|l|}
0.81 \\
\end{tabular} & 8.14 & 18.85 & 14.96 & 46.9 \\
\hline 40 & 21256 & \begin{tabular}{|c|}
98 \\
\end{tabular} & 2291 & 44.5 & 1021 & 11.1 & 8.1 & 9.8 & 3.50 & 1.06 & 9.76 & 16.79 & 8.75 & 41.67 \\
\hline
\end{tabular}


Effects of Agromorphological Traits of Ethiopian Mustard (Brasica Carinata A. Braun) Landraces in Oil and its Quality Traits

\begin{tabular}{|c|cr|c|c|c|c|c|c|c|c|c|c|c|c|c|}
\hline 41 & $"$ & 243750 & 85 & 2142 & 42.5 & 934 & 7.4 & 4.4 & 5.6 & 3.47 & 0.76 & 8.48 & 19.12 & 15.12 & 44.18 \\
\hline 42 & $"$ & 2243756 & 108 & 1859 & 42.7 & 797 & 11.2 & 8.8 & 10.6 & 3.66 & 1.01 & 10.01 & 16.97 & 10.32 & 41.17 \\
\hline 43 & $"$ & 243761 & 88 & 1931 & 43.5 & 846 & 8.9 & 6.6 & 8.2 & 3.53 & 0.93 & 9.44 & 17.44 & 11.48 & 43.29 \\
\hline 44 & $"$ & 243763 & 95 & 1348 & 42.1 & 563 & 7.5 & 5.4 & 6.6 & 3.95 & 0.87 & 9.92 & 17.32 & 11.86 & 42.60 \\
\hline 45 & $"$ & 208556 & 86 & 1879 & 44.2 & 846 & 7.5 & 5.1 & 6.2 & 3.72 & 0.89 & 9.06 & 16.97 & 13.84 & 43.91 \\
\hline 46 & $"$ & 208585 & 94 & 2142 & 46.0 & 973 & 10.0 & 7.8 & 9.1 & 3.65 & 0.87 & 8.49 & 17.34 & 15.73 & 44.22 \\
\hline 47 & Yellow dodolla & 85 & 3297 & 44.4 & 1478 & 6.9 & 4.4 & 5.5 & 3.21 & 0.93 & 8.02 & 17.52 & 14.55 & 43.29 \\
\hline 48 & $\begin{array}{c}\text { ZemY.Dodolla } \\
\text { (2) }\end{array}$ & 80 & 2603 & 43.8 & 1157 & 7.2 & 4.2 & 5.4 & 3.57 & 0.65 & 6.91 & 18.40 & 16.99 & 46.32 \\
\hline 49 & Local check & 85 & 2212 & 42.4 & 934 & 6.0 & 3.4 & 4.4 & 4.44 & 0.85 & 9.57 & 18.43 & 13.10 & 45.69 \\
\hline Range & & $79-$ & $904-$ & $39-46$ & $370-$ & $4.6-$ & $2.1-$ & $3.1-$ & $2.8-$ & $0.64-$ & $6.91-$ & $15.59-$ & $7.61-$ & $40.1-$ \\
\hline Mean & 113 & 3297 & & 1478 & 11.2 & 8.8 & 10.6 & 4.6 & 1.17 & 11.51 & 20.09 & 17.39 & 49.07 \\
\hline $\begin{array}{l}\text { CV } \\
(\%)\end{array}$ & & 93 & 1999 & 42.9 & 866 & 8.5 & 5.7 & 7.2 & 3.8 & 0.92 & 9.44 & 17.5 & 12.16 & 43.91 \\
\hline $\begin{array}{l}\text { LSD } \\
(0.05)\end{array}$ & & 3.38 & 24.08 & 2.477 & 24.86 & 18.4 & 20.6 & 36.8 & & & & 3.91 & 9.65 & 3.09 \\
\hline
\end{tabular}

DM: date of Maturity, SYP: Seed yield per plot, OC: oil content, OY: oil yield, LL, LW = leaf, width length respectively, $L A=$ leaf area, Y:yellow

Correlation Analysis: Correlation among various agro morphological, quantity and oil quality related traits are presented in Table 4. For the tested agro morphological traits within 49 Ethiopian mustard genotypes all of the characteristics showed high and significant correlation. Measurements of all agro morphologic, quantity and quality related traits were positively and significantly correlated with each other except negatively correlated lenolenic (r:-0.07) with leaf length(r:-0.22) and lenolenic with leaf area(r:-0.18). When we see the date maturity with all agro morphological and quality traits it was positively and highly associated with all traits correlated. The correlation date of maturity range for tested agro morphological traits(r: 0.301) for linolenic to (r: 0.879) for oil content. Similarly seed yield per plot correlation ranges r: 0.249 (for leaf area) to $\mathrm{r}$ : 0.995 (for oil yield per plot). Oil content was positively and highly correlated with erucic acid ( $\mathrm{r}$ : 0.927). The correlation between oil yield and erucic acid (r: 0.57) was the highest where as the least was between leaf area(r 0.260). Among tested genotypes for agro morphological traits correlation between oil content with erucic acid(r: 0.927), oil yield with erucic acid (r: 0.537), palmitic with erucic(r: 0.890) linoleic with erucic(r: 0.945) and lenolenic with erucic (r.0726) were the highest correlation. The correlation of leaf length with leaf width $(\mathrm{r}=0.94)$, as well as leaf area ( $\mathrm{r}: 0.97)$ was highly and significantly correlated with the component traits.

Table4. Correlation coefficient between 13 agro morphological traits of Ethiopian mustard landraces

\begin{tabular}{|c|c|c|c|c|c|c|c|c|c|c|c|c|c|c|c|}
\hline & DM & SYP & OC & OY & Palmic & Stearic & Oleic & Linoleic & Linolenic & Erucic & PL & LL & LW & LA \\
\hline DM & 1 & & & & & & & & & & & & & \\
\hline SYP & 0.465 & 1.000 & & & & & & & & & & & & \\
\hline OC & 0.879 & 0.688 & 1.000 & & & & & & & & & & & \\
\hline OY & 0.443 & 0.995 & 0.671 & 1.000 & & & & & & & & & & \\
\hline Palmic & 0.736 & 0.494 & 0.804 & 0.453 & 1.000 & & & & & & & & & \\
\hline Stearic & 0.852 & 0.460 & 0.739 & 0.459 & 0.521 & 1.000 & & & & & & & & \\
\hline Oleic & 0.847 & 0.438 & 0.765 & 0.424 & 0.660 & 0.902 & 1.000 & & & & & & & \\
\hline Linoleic & 0.743 & 0.534 & 0.884 & 0.496 & 0.875 & 0.489 & 0.611 & 1.000 & & & & & & \\
\hline Linolenic & 0.301 & 0.388 & 0.589 & 0.359 & 0.605 & -0.037 & 0.135 & 0.785 & 1.000 & & & & & \\
\hline $\begin{array}{c}\text { Erucic } \\
\text { acid }\end{array}$ & 0.801 & 0.572 & 0.927 & 0.537 & 0.890 & 0.556 & 0.608 & 0.945 & 0.726 & 1.000 & & & & \\
\hline PL & 0.523 & 0.136 & 0.278 & 0.136 & 0.161 & 0.520 & 0.453 & 0.062 & -0.231 & 0.143 & 1.000 & & & \\
\hline LL & 0.739 & 0.363 & 0.551 & 0.371 & 0.418 & 0.708 & 0.642 & 0.294 & -0.071 & 0.400 & 0.817 & 1.000 & & \\
\hline LW & 0.640 & 0.254 & 0.408 & 0.271 & 0.263 & 0.637 & 0.556 & 0.115 & -0.223 & 0.220 & 0.844 & 0.940 & 1.000 & \\
\hline LA & 0.680 & 0.249 & 0.439 & 0.260 & 0.309 & 0.661 & 0.583 & 0.170 & -0.177 & 0.278 & 0.879 & 0.970 & 0.983 & 1.000 \\
\hline
\end{tabular}

\section{CONCLUSION}

In this study, 49 Ethiopian mustard genotypes acquired from diverse zones/regions of Ethiopia were evaluated in simple lattice design with two replications at Holetta Agricultural Research Center, West 
Shewa zone, Therefore the present study was, executed with the objective of assessing the effect of agro morphological traits of Ethiopian mustard land races in relation to quantity and quality of oil production. The analysis of variance showed that there were significant differences among genotypes for all agro morphological, oil yield quantity and quality related traits compared. Among analyzed agro morphological traits highly and significantly difference was observed in date of maturity, oil content percent, petiole length, leaf length, leaf width, leaf area and for all oil quality related traits. Only seed yield per plot and oil yield was significant. The significant difference indicates the existence of genetic variability among the accessions that is important for selection and breeding program. For the tested agro morphological traits within 49 Ethiopian mustard genotypes all of the characteristics showed high and significant correlation. Measurements of all agro morphologic, quantity and quality related traits were positively and significantly correlated with each other except negatively correlated lenolenic with leaf length and lenolenic with leaf area. Further similar study on variability of metric characters using biotechnological tools would also help in substantiating the result obtained.

\section{REFERENCES}

[1] Adefris Teklewold. 2005. Diversity Study Based on Quality Traits and RAPD Markers and Investigation of Heterosis in Ethiopian Mustard. Ph.D. diss. Georg-August Univ. of Gottingen, Germany. 161p.

[2] Doweny R.K. and G. RÖbbelen. 1989. Brassica Species. In RÖbbelen G, Doweny RK and Ahri A (eds) Oil crops of the world. McGraw-Hill New York. pp. 339-359

[3] Gomez-Campo, C. and S. Prakash. 1999. Origin and domestication of the Brassica. pp. 33-58. In: GomezCampo C (ed.). Biology of Brassica Coenospecies. Elsevier, Amsterdam.

[4] Hemingway, J.S. 1976. Mustards Brassica species and Sinapsis alba (Cruciferae). In: Evolution of Crop Plants. N.W. Simmounds (ed.) Longan. London. 339p.

[5] Jane Muthoni.2010.Characterization of Ethiopian Mustard(Brassica carinata A. Braun)lines for vegetative agro morphological traits at Arusha,Tanzania.Jornal of Horti and forestry Vol.2(1)pp.002006

[6] Nigussie Alemayehu. 2001. Germplasm diversity and Genetics of Quality and Agronomic Traits in Ethiopian Mustard (Brassica carinata A. Braun). Ph.D. Thesis, George-August University of Gottingen, Germany

[7] Nigussie Alemayehu and Mesfin Abebe. 1994. Relative importance of some management factors in seed and oil yields of Ethiopian mustasrd (Brasica carinata Braun.) and Rapeseed (Brasica napus L.). Ethiopia. J. Agric. Sci. 14: 27-36

[8] SAS Institute INC., 2002- 2008. SAS*STAT, users guide, version 9.2, Cary N.C., SAS INC

[9] U.N. 1935. Genome analysis in Brassica with special reference to the experimental formation of B. napus and peculiar mode of fertilization. Jpn. J. Bot. 9: 389-452

[10] www. Seed laboratory Oregon state university. Oil, Protein and moisture Determination using NMR

[11] Yared Semahegn. 2010. Genetic diversity and Relationship among Association among Ethiopian mustard (Brassica carinata A. Braun) genotypes based on their agronomic and quality Traits. M.Sc. Thesis Presented to the School of Graduate Studies of Jima University. 75p.

[12] Rabbani, M. A., A. Iwabuchi, Y. Murakami, T. Suzuki and K. Takayanagi.1999. Collection, Evaluation and Utilization of Oilseed Mustard (Brassica juncea L.) in Pakistan. Pakistan Journal of Biological Sciences, 2 (1): 88-94, 1999

[13] Revilla, P. and W.F. Tracy, 1995.Morphological characterization and classification of open-pollinated sweet corn cultivars. J. Am. Soc. Hortic. Sci., 120: 112-118.

Citation: Fekadu Amsalu, "Effects of Agromorphological Traits of Ethiopian Mustard (Brasica Carinata A. Braun) Landraces in Oil and its Quality Traits" International Journal of Research Studies in Agricultural Sciences (IJRSAS), 2019; 5(6), pp. 33-39, http://dx.doi.org/10.20431/2454-6224.0506004

Copyright: () 2019 Authors. This is an open-access article distributed under the terms of the Creative Commons Attribution License, which permits unrestricted use, distribution, and reproduction in any medium, provided the original author and source are credited. 